\title{
Enzymatic Hydrolysis of Cassava Starch for Production of Bioethanol with a Colombian Wild Yeast Strain
}

\author{
Mónica I. Ruiz, ${ }^{*, a}$ Clara I. Sanchez, ${ }^{b}$ Rodrigo G. Torreses ${ }^{a}$ and Daniel R. Molina ${ }^{*, a}$ \\ ${ }^{a}$ Escuela de Química, Facultad de Ciencias and ${ }^{b}$ Escuela de Bacteriología y Laboratorio Clínico, \\ Facultad de Salud, Universidad Industrial de Santander, Cra 27 Calle 9, Bucaramanga, Colombia
}

\begin{abstract}
A hidrólise enzimática do amido de mandioca para produção de xaropes de glucose foi avaliada usando alfa-amilase de Bacillus licheniformis e glucoamilase de Aspergillus níger. Também, uma mistura enzimática composta de $\alpha$-amylase de Aspergillus kawachi e glucoamilase de Aspergillus níger foi testada. As condições da enzima para a hidrólise do amido foram otimizadas por um planejamento fatorial experimental $\left(3^{3} \times 2\right)$ usando como variáveis a concentração do substrato, a relação enzima/ substrato e o tempo de reação. As condições ótimas de reação com $100 \mathrm{~g}$ de amido per $\mathrm{L}$ foram: $\alpha$-amilase $\mathrm{pH} 5,0,80^{\circ} \mathrm{C}$ e $130,5 \mathrm{U} \mathrm{g}^{-1}$ de amido; glucoamilase $\mathrm{pH} 4,5,70{ }^{\circ} \mathrm{C}$ e $81,5 \mathrm{U} \mathrm{g} \mathrm{g}^{-1}$ de amido. Adicionalmente, as condições ótimas da mistura enzimática foram $\mathrm{pH} 4,5,46{ }^{\circ} \mathrm{C}$ e $16,4 \mathrm{U} \mathrm{g}^{-1}$ de amido. Finalmente, a produção de álcool usando xaropes de glucose a partir do amido hidrolisado enzimaticamente foi realizada usando uma cepa selvagem de Candida $s p$ isolada do caldo de cana de açúcar, obtendo produtividades em etanol volumétrico em torno de $1,8-3,2 \mathrm{~g} \mathrm{~L}^{-1} \mathrm{~h}^{-1}$.
\end{abstract}

Enzymatic hydrolysis of cassava starch for producing glucose syrups was evaluated using alpha-amylase from Bacillus licheniformis and glucoamylase from Aspergillus niger. Moreover, an enzyme mixture of $\alpha$-amylase from Aspergillus kawachi and glucoamylase from Aspergillus niger was tested. Enzyme conditions for starch hydrolysis were optimized by a factorial experimental design $\left(3^{3} \times 2\right)$ using as variables substrate concentration, enzyme/substrate ratio and time reaction. Optimal enzyme reactions with $100 \mathrm{~g}$ of starch per $\mathrm{L}$ were: $\alpha$-amylase at $\mathrm{pH} 5.0,80^{\circ} \mathrm{C}$ and enzyme dosage of $130.5 \mathrm{U} \mathrm{g}^{-1}$ of starch; and glucoamylase, $\mathrm{pH} 4.5,70^{\circ} \mathrm{C}$ and enzyme dosage of $81.5 \mathrm{U} \mathrm{g} \mathrm{g}^{-1}$ of starch. Additionally, optimal conditions for the enzymatic mixture were $\mathrm{pH} 4.5,46{ }^{\circ} \mathrm{C}$, and enzyme dosage of $16.4 \mathrm{U} \mathrm{g}^{-1}$ of starch. Finally, alcohol production using glucose syrups from enzymatically-hydrolyzed starch was carried out with a wild strain of Candida $s p$ isolated from sugar cane juice, obtaining volumetric ethanol productivities around 1.8-3.2 $\mathrm{g} \mathrm{L}^{-1} \mathrm{~h}^{-1}$.

Keywords: cassava starch, enzymatic hydrolysis, amylases, bioethanol

\section{Introduction}

Increasing on energetic requirements and atmospheric contamination by combustion gases, has opened searching for new, safe, effective and more accessible energy sources. For this aim, biofuels production from different agricultural sources, such as agroindustrial by-products, vegetable materials as woods, among others, has recently started-up. ${ }^{1,2}$ Biofuels can be produced by many different types of substrates. Among these, cassava (Manihot esculenta Crantz), a plant with high starch content, is considered a cheap, abundant and renewable resource for production of fermentable glucose syrups and dextrins. Moreover, it is easily produced in tropical and sub-tropical zones, mainly in Asia, South-America and South-Africa. ${ }^{3}$

*e-mail: dmolina@uis.edu.co
For obtaining glucose from cassava starch, an amylose/ amylopectin ratio of $18 / 82 \%$ is hydrolyzed by an amylolytic enzymatic complex. ${ }^{4-6}$ These conventional processes are carried out in three steps: gelatinization, liquefaction and saccharification. Gelatinization is an important step where starch grains are heated with excess of water to increase amylopectin amorphous region and enzyme accessibility. ${ }^{7-9}$

On the other hand, liquefaction is carried out by amylases that hydrolyze the chemical bond $\alpha-(1-4)$ of starch, producing dextrin, maltose, maltotriose and maltopentoses with a dextrose equivalent (DE) below 30. This enzyme processing of starch allows a rapid reduction in the viscosity of the solution. ${ }^{10,11}$ Amylolyltic enzymes can be obtained from different sources. Among these, we can find thermostable bacterial enzymes from Bacillus licheniformis or B. amyloliquefaciens, whose are suited for liquefaction, because this step is performed at high temperatures (80-110 $\left.{ }^{\circ} \mathrm{C}\right)$. Finally, saccharification 
process of partially hydrolyzed starch is carried out at lower temperatures $\left(60-70{ }^{\circ} \mathrm{C}\right)$. In this case are used enzymes such as glucoamylase (amyloglucosidase) obtained from Aspergillus niger or Rhizopus sp. These enzymes hydrolyze the chemical bonds $\alpha-(1-4)$ and $\alpha-(1-6)$, to obtain products such as maltose or D-glucose syrups with DE around 40 and 96, respectively. ${ }^{1,10-12}$

These amylolytic enzymes commonly are used in soluble solutions and they can be susceptible to inhibition for both reaction substrates and/or products. For this reason, identification and optimization of reaction conditions that affect enzymatic activity could improve economic and technological feasibility of this bioprocess. Among these different conditions are: temperature, $\mathrm{pH}$, reaction time, enzyme concentration, viscosity, mixing rates, ionic strength, calcium concentration, etc. ${ }^{11,15,16}$ Moreover, native starch is little soluble in water and resistant to hydrolysis at mild conditions. For this reason, it needs to carry out hydrothermal process for the gelatinization. ${ }^{14}$ However, a high energetic requirement for this process increases economical production costs of starch hydrolysis. ${ }^{8}$ In this work, we evaluated different amylolytic enzymes for obtaining the best conditions for hydrolysis of cassava starch, aimed to production of fermentable glucose syrups.

\section{Experimental}

\section{Cassava starch and amylolytic enzymes}

Cassava starch was obtained from a Starch Flour Plant-Manzanarez Ltda. Co. (Bucaramanga, Colombia). This starch product had a moisture content of 7 and 93\% of starch. Moisture content in the cassava starch was determined by drying a starch sample to constant weight. Enzymes used in this study were the following: Liquozyme ${ }^{\circledast}$ SC DS, Spirizyme ${ }^{\circledast}$ Fuel from Novozymes, and Stargen ${ }^{\mathrm{TM}} 001$ from Genecor International. These amylases are specialized for hydrolyzing starch from cereals such as corn and wheat.

\section{Pre-treatment of cassava starch}

Starch was dissolved in water or $0.016 \mathrm{~mol} \mathrm{~L}^{-1}$ sodium acetate buffer, $\mathrm{pH}$ 4.0. This starch solution was heated at $66{ }^{\circ} \mathrm{C}^{17}$ under mechanical shaking $390 \mathrm{rpm}$ by $30 \mathrm{~min}$.

\section{Enzymatic hydrolysis of cassava starch}

Starch hydrolysis was performed by two different methodologies. In the first one, it was carried out in two consecutive steps: liquefaction and saccharification. This procedure was performed in a batch reactor stirred at $390 \mathrm{rpm}$. In the liquefaction step, starch was gelatinized by thermal treatment and treated with alpha-amylase (Liquozyme ${ }^{\circledR}$ SC DS de Novozymes) for obtaining dextrins from cassava starch. Dextrins were determined as dextrose equivalent (DE) (equation 1) and reducing sugars, and reported in terms of units of enzymatic activity $\mathrm{U}$ (defined as $1 \mu \mathrm{mol}$ of reducing sugar released per min), using the 3,5-di-nitro-salicylic acid (DNS) colorimetric method. ${ }^{14}$ The saccharification step was carried out with glucoamylase (Spirizyme ${ }^{\circledR}$ Fuel from Novozymes) producing glucose syrups from dextrins obtained in the previous liquefaction step. Additionally, bioprocess efficiency was determined quantifying glucose concentration by spectrophotometry using a glucose oxidase method (Glucose Kit, BioSystems ${ }^{\circledast}$, S.A). ${ }^{19,20}$

In the second methodology, a simultaneous liquefaction and saccharification starch hydrolysis was performed in batch mode. In this case, it was used non-gelatinized starch, adding an enzymatic mixture of $\alpha$-amylase and glucoamilase (Stargen ${ }^{\mathrm{TM}}$ 001) and the same reaction conditions described previously.

$\% \mathrm{DE}=\frac{\mathrm{g} \text { reducing sugar expressed as gluose }}{\mathrm{g} \text { dry solid weight }} \times 100$

\section{Effect of temperature on enzymatic activity of amylases}

The enzymatic activity was determined for each amylolytic enzyme at different temperatures. Liquozyme ${ }^{\circledR}$ SC DS and Spirizyme ${ }^{\circledR}$ Fuel were evaluated at 66, 70 and $80^{\circ} \mathrm{C}$, while Stargen ${ }^{\mathrm{TM}} 001$ was determined at 30,47 and $56^{\circ} \mathrm{C}$. Periodically, samples $(1 \mathrm{~mL})$ from enzyme reactions were withdrawn for determination of reducing sugars and quantification of DE.

Effect of $\mathrm{pH}$ and substrate concentration on enzymatic activity of amylases

The influence of $\mathrm{pH}$ on enzymatic activity was determined in a range of 3.0-6.0. Enzymatic activity was tested using substrate concentrations in the range of 100-300 $\mathrm{g} \mathrm{L}^{-1}$, determining enzyme activity and DE parameters as previously described.

\section{Optimization of cassava hydrolysis}

Once reaction conditions for enzymatic hydrolysis of cassava starch were determined, starch hydrolysis using non-diluted enzymes and high substrate concentrations 
was evaluated. In this case, enzymatic hydrolysis was performed at constant $\mathrm{pH}$ and temperature conditions previously established for these enzymes, ${ }^{8,23}$ similar values for these parameters to those reported in the technical sheet for these enzymes. ${ }^{21,22,24} \mathrm{An}$ experimental design of $3^{3}$ using 2 measurements by run (see Table 1) was carried out for optimization of saccharification process for analyzing and validating the most important variables affecting this enzymatic process.

The experimental design for three variables, including enzyme/substrate, substrate concentration and time at three levels (low (-1), medium (0) and high (1)) (Table 1) were used for screening based on our previously study. The total number of experiments to be performed was $\left(\mathrm{n}^{\mathrm{k}}\right) \mathrm{r}$, where $\mathrm{n}$ is the number of levels, $\mathrm{k}$ is the number of variables, and $\mathrm{r}$ is the number of replicates for the runs obtaining a total of (27) $\times 2=54$ experiments. To avoid bias, the 54 runs were performed in a totally random order. Finally, the statistical significance was determined by $P$-value, and the proportion of variance explained by the model obtained was given by the multiple coefficient of determination, $\mathrm{R}^{2}$.

Table 1. Matrix for the experimental design of saccharification process of cassava starch using spirizyme fuel from Novozymes

\begin{tabular}{lcccc}
\hline \multirow{2}{*}{ Parameter } & Symbol & \multicolumn{3}{c}{ Level } \\
\cline { 3 - 5 } & & -1 & 0 & 1 \\
\hline $\begin{array}{l}\text { Enzyme/Substrate } \times 10^{3} / \\
\left(\mathrm{U} \mathrm{g} \text { of }^{-1} \text { starch }\right)\end{array}$ & $\mathrm{X}_{1}$ & 1.9 & 3.9 & 5.9 \\
Substrate $/\left(\mathrm{g} \mathrm{L}^{-1}\right)$ & $\mathrm{X}_{2}$ & 200 & 300 & 400 \\
time / min & $\mathrm{X}_{3}$ & 15 & 30 & 45 \\
\hline
\end{tabular}

\section{Culture medium and yeast fermentation conditions}

Inoculum was constituted by wild Candida $s p$ yeast pre-cultured for $12 \mathrm{~h}$ at $37{ }^{\circ} \mathrm{C}$ and under microaerophilic conditions (without shaking), using a liquid medium solution YPG, containing glucose $\left(150 \mathrm{~g} \mathrm{~L}^{-1}\right)$, peptone and yeast extract $\left(10 \mathrm{~g} \mathrm{~L}^{-1}\right)$. Afterwards, a fermentation medium YG containing glucose $\left(150 \mathrm{~g} \mathrm{~L}^{-1}\right)$, yeast extract $\left(10 \mathrm{~g} \mathrm{~L}^{-1}\right)$ was used for ethanol production.

Optimization of enzymatic saccharification process of cassava starch and ethanol production by wild yeasts strain

For these experiences, it was carried out starch hydrolysis at optimal conditions, and hydrolyzed starch containing fermentable sugars was used as carbon source for ethanol production by a native strain of Candida sp. Culture medium was inoculated with $0.3 \mathrm{~g} \mathrm{DCW} \mathrm{L}^{-1}$ of wild yeast, working at $0.2 \mathrm{~mol} \mathrm{~L}^{-1}$ sodium acetate buffer, $\mathrm{pH} 5,35^{\circ} \mathrm{C}$ and $120 \mathrm{rpm}$ of stirring, using a Shaker Max Q Mini 4450.
Ethanol production was performed by different methodologies, working with $250 \mathrm{~g}$ of starch per $\mathrm{L}$ as carbon source for ethanol fermentation. In the first one, starch hydrolysis and ethanol fermentation were carried out in consecutive steps, using $9.3 \times 10^{3} \mathrm{U} \mathrm{g}^{-1}$ of starch of $\alpha$-amylase Liquozyme ${ }^{\circledR}$ SC DS for starch hydrolysis and $3.7 \times 10^{3} \mathrm{U} \mathrm{g}^{-1}$ of starch of the glucoamylase Spirizyme ${ }^{\circledR}$ fuel from Novozymes. In the second one, a simultaneous saccharification and fermentation (SSF) process was performed adding $39.3 \mathrm{U} \mathrm{g}^{-1}$ of starch of an enzymatic mixture of $\alpha$-amylase and glucoamilase Stargen $^{\mathrm{TM}}$ 001) from Genecor. At different times (7, 20, 30 and $45 \mathrm{~h}$ of fermentation), samples were withdrawn from the fermentation broth. The samples were centrifuged at $10.000 \mathrm{~g}$ for $15 \mathrm{~min}$. Supernantants were used for determination of ethanol, reducing sugars and biomass concentrations. Ethanol was determined by headspace-gas chromatography (HS-GC) using a gas chromatographHewlett Packard 5890 according to Hailong et al. ${ }^{25}$ Biomass concentration was determined by dry cell weight (DCW) methodology. Samples from fermentation broths were withdrawn at different times and centrifuged at $10.000 \mathrm{~g}$ and subsequently washed with distilled water 3 times $(3 \times)$. Subsequently were dried at $105^{\circ} \mathrm{C}$ until to obtain constant weight. Alternatively, dilutions from fermentation broths (in exponential phase) were made for determination of cell concentration by turbidimetry at $650 \mathrm{~nm}$ and correlated with in $\mathrm{g}$ DCW L ${ }^{-1}$ determinations.

\section{Results and Discussion}

\section{Enzymatic hydrolysis of cassava starch}

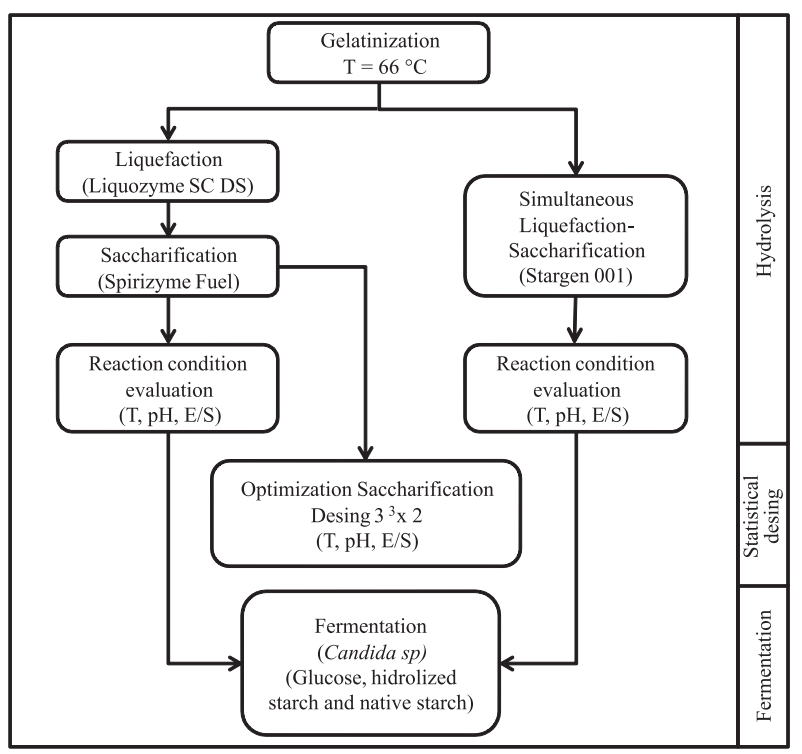

Figure 1. The schematic flow diagram of the enzymatic hydrolysis procedure. 


\section{Effect of enzyme/substrate ratio on enzymatic hydrolysis}

In this study, different enzyme/substrate ratios (E/S) were tested. Higher DE values were used as criterion for selecting an enzyme for hydrolysis of cassava starch. Best results were obtained with a ratio of $130.5 \mathrm{U} \mathrm{g}^{-1}$ of starch for enzyme from Novozymes (Figure 2A) $81.6 \mathrm{U} \mathrm{g}^{-1}$ of starch for saccharification process (Figure 2B) and $16.4 \mathrm{U} \mathrm{g}^{-1}$ of starch for enzymatic mixture from Genecor (Figure 2C). The enzyme reaction conditions were the following: liquefaction and saccharification as described in pre-treatment starch, while in simultaneous liquefaction-
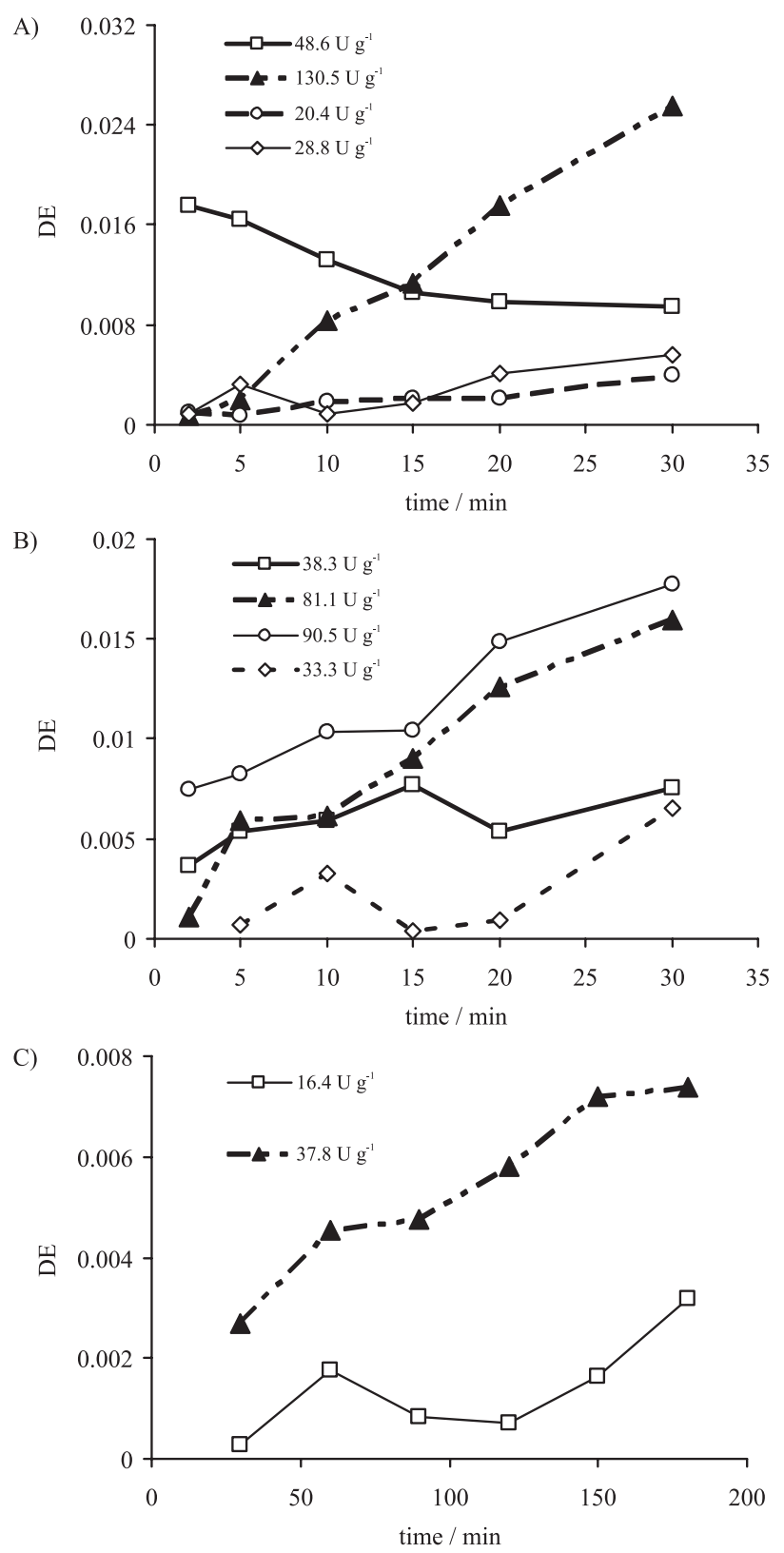

Figure 2. Dextrose equivalent production at different enzyme/substrate ratios during enzymatic hydrolysis of cassava starch. saccharification were carried out at $\mathrm{pH} 4.0$ and $37^{\circ} \mathrm{C}$. For both process we used a starch concentration of $100 \mathrm{~g} \mathrm{~L}^{-1}$. Additionally, at higher E/S ratios, a both increase on released DE became and reaction rates were achieved. Nevertheless, E/S ratios reached in this study were lower than reported from providers ${ }^{21,22,24}$ and Zhao et al. ${ }^{23}$

\section{Effect of temperature on enzymatic activity}

This study was achieved at the same reaction conditions used to study effect of enzyme/substrate ratio on enzymatic hydrolysis. In Figure 3 are shown results of effect of temperature on different amylolytic enzymes hydrolyzing cassava starch. Optimal reaction temperatures varied and were dependent on type of enzyme. In general, initial hydrolysis rate was increased with temperature, obtaining optimal hydrolysis rates for Liquozyme ${ }^{\circledR}$ SC DS, Spirizyme ${ }^{\circledR}$ Fuel (amylase and glucoamylase from Novozymes) at 80 and $70{ }^{\circ} \mathrm{C}$, respectively. These results are according to results obtained by Zhao et al..$^{23}$ On the other hand, we obtained an optimal temperature of $47^{\circ} \mathrm{C}$ for Stargen ${ }^{\mathrm{TM}} 001$, achieving similar data to those reported by Wang et al. ${ }^{26}$ However, starch hydrolysis was decreased at high temperatures, due to thermal inactivation of amylolytic enzymes (Wu and Miao, ${ }^{27}$ Morales et al. ${ }^{12}$ ).

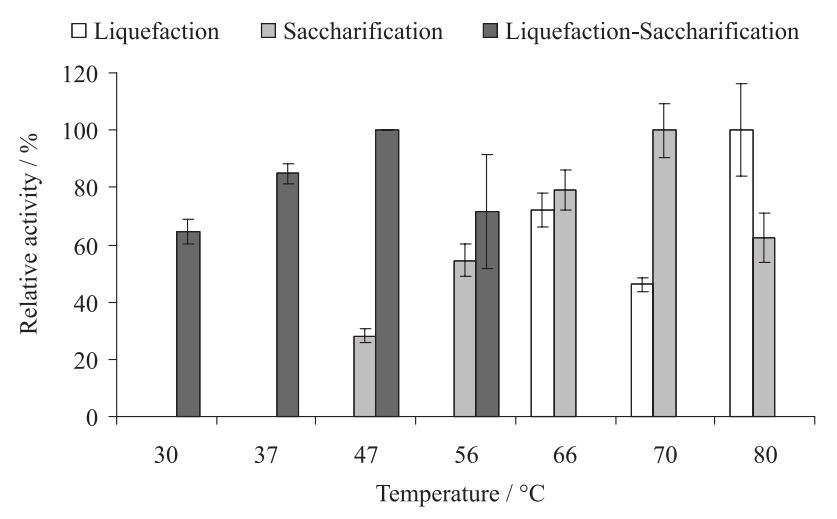

Figure 3. Effect of temperature on enzyme activity during enzymatic hydrolysis of cassava starch.

\section{Effect of pH on enzymatic activity}

In these studies, we worked in range of $\mathrm{pH}$ values with high catalytic activity. ${ }^{13}$ This study was achieved at the same reaction conditions used to study effect of enzyme/ substrate ratio on enzymatic hydrolysis. In Figure 4 are shown results of $\mathrm{pH}$ effect on enzymatic activity. In this figure we can see that optimal $\mathrm{pH}$ were 5.0, 4.5 and 4.0, for liquefaction, saccharification and simultaneous liquefaction and saccharification, respectively. These values were in the range to those found by Zhao et al. ${ }^{23}$ for enzymes from 
Novozymes, and Stargen ${ }^{\mathrm{TM}} 001$ obtained by Wang and co-workers. ${ }^{23,26}$

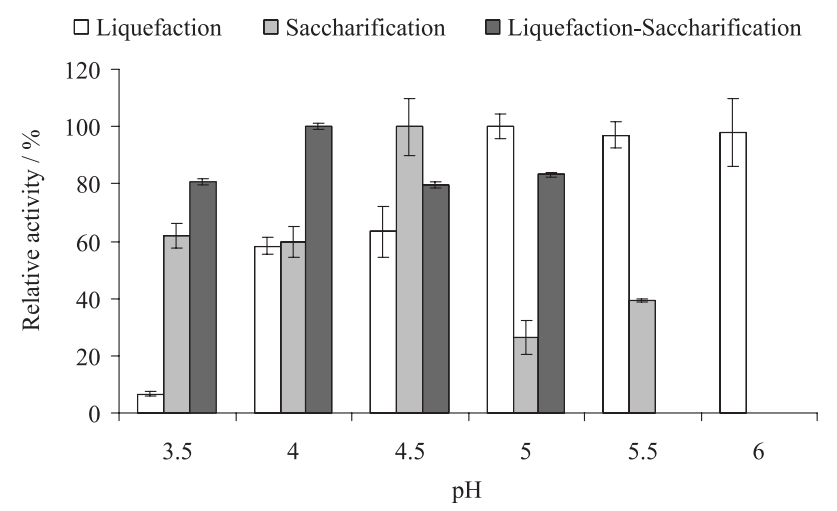

Figure 4. Effect of $\mathrm{pH}$ on enzyme activity during the starch hydrolytic bioprocess.

\section{Effect of substrate concentration}

In Figure 5 is shown the effect of substrate concentration on enzymatic activity at optimal $\mathrm{pH}$ and temperature determined in previous studies. In this figure is observed that increasing in substrate concentration produced a decrease in enzymatic activity on starch hydrolysis. This effect could be due to diffusional constraints during the enzymatic hydrolysis of starch, ${ }^{16}$ caused mainly by increasing in viscosity by gelatinized starch. Similar observations have been reported by Baks et al. ${ }^{28}$ working with high starch concentrations ( $650 \mathrm{~g}$ of strach $\left.\mathrm{L}^{-1}\right)$. On the other hand, it is possible that enzymatic inhibition of amylases could be produced by high substrate concentrations.

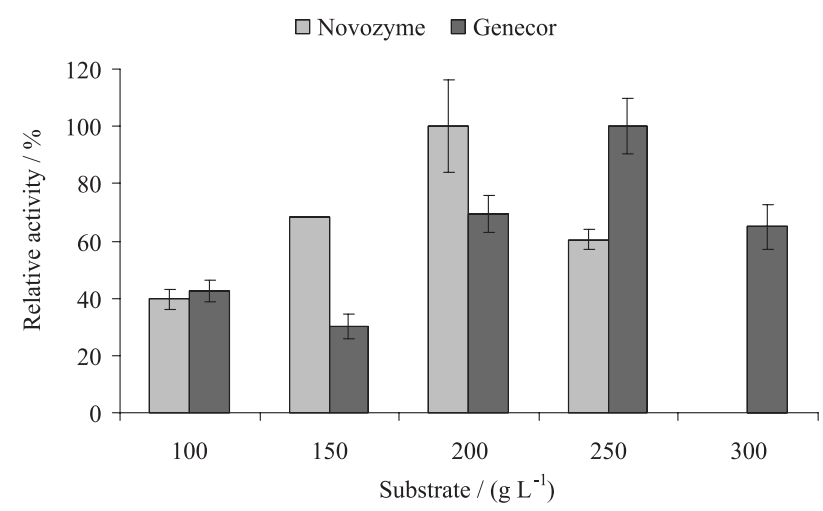

Figure 5. Effect of substrate concentration on enzyme activity.

For this reason, it was selected $200 \mathrm{~g}$ of starch $\mathrm{L}^{-1}$ of cassava starch for enzymes from Novozymes and $250 \mathrm{~g}$ of starch per $\mathrm{L}$ ) for the enzyme from Genecor. ${ }^{24,25}$ However, these enzymes are not saturated at these starch concentrations. On the other hand, stirring rate was kept at $390 \mathrm{rpm}$ during all starch hydrolysis process, and it was not detrimental for enzyme stability, ${ }^{9}$ allowing god mass transfer and mixing performances for enzymatic starch hydrolysis. ${ }^{16}$

\section{Optimization of starch hydrolysis by factorial design}

Analysis of variance (Table 1) indicates that the secondorder polynomial model (equation 2) was significant and adequate to represent the actual relationship between the response (glucose released by enzymatic starch hydrolysis in units of concentration $\left.\left(\mathrm{g} \mathrm{L}^{-1}\right)\right)$ and the significant variables, with a very small $P$-value $(\mathrm{p}<0.05)$ and a coefficient of determination $\mathrm{R}^{2}=0.7977$.

$$
\begin{aligned}
& Y=194.8+40.3 X_{1}+39.0 X_{2}+29.8 X_{3}+5.6 X_{1}^{2}+22.9 X_{1} X_{2}+ \\
& 8.9 X_{1} X_{3}-9.4 X_{2}^{2}+0.86 X_{2} X_{3}-12.1 X_{3}^{2}
\end{aligned}
$$

where $\mathrm{Y}$ is glucose concentration $\left(\mathrm{g} \mathrm{L}^{-1}\right)$ and $\mathrm{X}_{1}, \mathrm{X}_{2}$ and $\mathrm{X}_{3}$ are enzyme/substrate ratio $\left(\mathrm{U} \mathrm{g}^{-1}\right.$ of starch), starch $\left(\mathrm{g} \mathrm{L}^{-1}\right)$ and time ( $\mathrm{min})$, respectively.

This equation was statistically adjusted and could explain $75.6 \%$ of variability on glucose concentration which means that $24.4 \%$ is due to factors not considered in this investigation (uncertainty), with $23 \%$ of mean absolute error.

From these regression coefficients obtained in the equation 2, it is possible to determine that the most linear important independent variables for an efficient production of glucose from cassava starch are: $\mathrm{X}_{1}, \mathrm{X}_{2}$ and $\mathrm{X}_{3}$ variables. This equation corroborates that these variables are very significant (with a very small $P$-value $(\mathrm{p}<0.05)$; see Table 2), followed by the interaction of linear variables of $\mathrm{X}_{2} \mathrm{X}_{1}$, for finding finally other second order combinations, with minimal contribution to the response variable or indirect relation over response.

Table 2. Analysis of variance for synthetic variables pertaining to response glucose concentration $\left(\mathrm{g} \mathrm{L}^{-1}\right)$

\begin{tabular}{lcc}
\hline Source $^{\mathrm{a}}$ & Df & $P$-value \\
\hline $\mathrm{X}_{1}$ & 1 & $<0.0000$ \\
$\mathrm{X}_{2}$ & 1 & $<0.0000$ \\
$\mathrm{X}_{3}$ & 1 & $<0.0000$ \\
$\mathrm{X}_{1}{ }^{2}$ & 1 & 0.5431 \\
$\mathrm{X}_{1} \mathrm{X}_{2}$ & 1 & $<0.0009$ \\
$\mathrm{X}_{1} \mathrm{X}_{3}$ & 1 & 0.1699 \\
$\mathrm{X}_{2}{ }^{2}$ & 1 & 0.3048 \\
$\mathrm{X}_{2} \mathrm{X}_{3}$ & 1 & 0.8943 \\
$\mathrm{X}_{3}{ }^{2}$ & 1 & 0.1896 \\
\hline
\end{tabular}

${ }^{\mathrm{a}} \mathrm{X}_{1}, \mathrm{X}_{2}$ and $\mathrm{X}_{3}$ are enzyme/substrate ratio $\left(\mathrm{U} \mathrm{g}^{-1}\right.$ of starch), starch $\left(\mathrm{g} \mathrm{L}^{-1}\right)$ and time $(\mathrm{min})$, respectively. 
The optimal saccharification parameters were obtained by solving the regression equation (equation 2). The optimal parameters were: $5.9 \mathrm{U} \mathrm{g}^{-1}$ of starch of spirizyme fuel, $400 \mathrm{~g} \mathrm{~L}^{-1}$ dry matter and $45 \mathrm{~min}$ for saccharification. Under optimal conditions obtained by design we reached a glucose yield of $320.7 \mathrm{~g} \mathrm{~L}^{-1}$.

\section{Ethanol production by wild yeast using hydrolyzed cassava starch as substrate}

The results obtained during fermentation of hydrolyzed starch (Table 3) were favorable for both hydrolytic processes used in this study. We used two approaches for ethanol production: first one, starch hydrolysis and then yeast fermentation, and second one, simultaneous saccharification and fermentation (SSF).

Based on the obtained results the time of the overall process of ethanol production may increase in the simultaneous saccharification and fermentation. The energy savings could be attained since the SSF process was effectively performed at $35{ }^{\circ} \mathrm{C}$, which is a lower temperature than the optimal temperature from the action of enzymes for starch hydrolysis and then yeast fermentation $\left(>60^{\circ} \mathrm{C}\right)$.

In addition, the SSF process bring some advantages such as prevention of inhibition by substrate concentration, and that as the sugars are produced, these are fermented also avoids previous process of starch hydrolysis and the use of other process.

Table 3. Kinetic parameters of ethanol production obtained during fermentation of a wild yeast strain using different fermentable sugar as carbon sources

\begin{tabular}{lccc}
\hline Fermentation substrate & $\mathrm{qp} / \mathrm{h}^{-1}$ & $\mathrm{Qp} /\left(\mathrm{g} \mathrm{L}^{-1} \mathrm{~h}^{-1}\right)$ & $\mathrm{t}-\mathrm{f} / \mathrm{h}$ \\
\hline Hidrolized starch & 64.8 & 3.2 & 20 \\
Native starch & 36.4 & 1.8 & 20 \\
Glucose & 82.5 & 3.6 & 23 \\
\hline
\end{tabular}

$\mathrm{qp}=$ specific productivity; $\mathrm{Qp}=$ volumetric productivity; $\mathrm{t}-\mathrm{f}=$ fermentation time.

We achieved ethanol production values comparable with data reported by Wang and co-workers ${ }^{23}$ and Białas et al. ${ }^{29}$ These authors used starch from crude corn and flour corn, and obtained volumetric productivities around 1.6 and $1.7 \mathrm{~g} \mathrm{~L}^{-1} \mathrm{~h}^{-1}$, respectively. Other authors have used other enzymes and worked with simultaneous saccharification and fermentation of cassava starch. In these cases, maximum ethanol productivities, ranging from 0.95 to $2.1 \mathrm{~g} \mathrm{~L}^{-1} \mathrm{~h}^{-1}$ and using free and co-immobilized cells of Saccharomyces diastaticus and Zymomonas mobilis, ${ }^{30}$ Saccharomyces cerevisiae IR2, ${ }^{31}$ Saccharomyces cerevisiae
CHY1011 and CHFY0901 ${ }^{32}$ have been produced. Likewise, ethanol productivities in the range of 0.24 to $0.48 \mathrm{~g} \mathrm{~L}^{-1} \mathrm{~h}^{-1}$, and using Cassava pulp and a thermotolerant yeast Candida tropicalis $\mathrm{BCC} 7755^{33}$ and a native Saccharomyces cerevisiae Kyokai $N .7^{34}$ have been obtained.

\section{Conclusions}

We worked in the saccharification of cassava starch using commercial enzymes: $\alpha$-amylase Liquozyme ${ }^{\circledR}$ SC DS and glucoamylase Spirizyme ${ }^{\circledR}$ Fuel from Novozymes, and a mixture of $\alpha$-amylase and glucoamylase Stargen ${ }^{\mathrm{TM}}$ 001 from Genecor obtaining high concentrations of glucose (around $300 \mathrm{~g} \mathrm{~L}^{-1}$ ) when reaction conditions of $\mathrm{pH}$, temperature and substrate/enzyme ratios were optimized.

Additionally, it was possible to save time and energy on the conversion of cassava starch to glucose by using novel enzymes like Liquozyme SC DS and spirizyme fuel from Novozyme and Stargen 001 from Genecor. Saccharification rates were improved dramatically by using these enzymes, reducing in $50 \%$ the time for both liquefaction and saccharification process compared to hydrolysis of starch obtained from other sources.

Finally, production of glucose syrups from cassava starch pre-gelatinized was not favourable with the enzyme mixture Stargen. However, simultaneous saccharification and fermentation (SSF) studies with enzyme mixture Stargen and native cassava starch is quite promising because this bioprocess increase ethanol productivity by reducing of pre-fermentation times and energy required for conventional enzymatic starch hydrolysis.

\section{Acknowledgments}

We thanks to Ministerio de Agricultura y Desarrollo Rural from Colombia (Grant No. 2007D3321-639), and the Vicerrectoria de Investigación y extensión (VIE)-UIS (Project No. 5645) for financial support. Finally, we are very grateful with Novozymes and Genecor International for give us amylolytic enzymes used in this research.

\section{References}

1. Nigam, P. S.; Singh, A.; Prog. Energy combust. Sci. 2011, 37, 52.

2. Demirbas, A.; Prog. Energy combust. Sci. 2007, 33, 1.

3. Patle, S.; Lal, B.; Biomass Bioenergy 2008, 32, 596.

4. Gunaratne, A.; Hoover, R.; Carbohydr. Polym. 2002, 130, 452.

5. Hoover, R.; Carbohydr. Polym. 2001, 45, 253.

6. Uthumporna, U.; Zaidul, I. S. M.; Karima, A. A.; Food Bioprod. Process. 2010, 88, 47. 
7. Tester, R. F.; Qi, X.; Karkalas, J.; Anim. Feed Sci. Technol. 2006, 130, 39.

8. Shariffaa, Y. N.; Karima, A. A.; Fazilaha, A.; Zaidulb, I. S. M.; Food Hydrocolloids 2009, 23, 434.

9. Van der Veen, M. E.; Veelaert, S.; Vander Goot, A. J.; Boom, R. M.; J. Food. Eng. 2006, 75, 178.

10. Plácido, M. G. R.; Rodrigues do Canto, L.; Amante, E. R.; Quim. Nova 2005, 28, 596.

11. Leveque, E.; Janecek, S.; Haye, B.; Belarbi, A.; Enzyme Microb. Tech. 2000, 26, 3.

12. Morales, S.; Alvarez, H.; Sanchez, C.; Food Bioprod. Process. 2008, 86, 25.

13. Nagodawithana, T.; Reed, G.; Enzymes in Food Processing, $3^{\text {th }}$ ed.; Academic press: San Diego, New York, 1993, p. 122.

14. Mitsuiki, S.; Mukae, K.; Sakai, M.; Goto, M.; Hayashida, S.; Furukawa, S.; Enzyme Microb. Tech. 2005, 37, 410.

15. Özbek, B.; Yuceer, S.; Process Biochem. 2001, 37, 87.

16. Apar, D. C.; Özbek, B.; Process Biochem. 2005, 40, 1367.

17. Mishra, S.; Rai, T.; Food Hydrocolloids 2006, 20, 557.

18. Whistler, R. L.; Smith, R. J.; Be Miller, J. J. N.; Wolfrom, M. L.; Methods in Carbohydrate Chemistry, Starch, Academic Press: New York,1964, vol. IV, p. 67.

19. GLUCOSE (Glucose Oxidase/Peroxidase). Clinical ChemistryBiochemistry Application Sheet: Reagents for Measurement of Glucose Concentration. http://www.biosystems-sa.com, accessed in May 2010.

20. Ochoa, S.; Yoo, A.; Repke, J-U.; Wozny, G.; Yan, D. R.; Biotechnol. Prog. 2007, 23, 1454.

21. LIQUOZYME ${ }^{\circledR}$ SC DS; Fuel Ethanol Application Sheet: Liquefaction of Starch from Dry-milled Grains. http://www. novozymes.com, accessed in May 2010.
22. SPIRIZYME ${ }^{\circledR}$ FUEL; Fuel Ethanol Application Sheet: Enzymes that make Glucose From Liquefied Grains. http://www. novozymes.com, accessed in May 2010.

23. Zhao, R.; Bean, S. R.; Wang, D.; Park, S. H.; Schober, T. J.; Wilson, J. C.; J. Cereal. Sci. 2009, 49, 230.

24. STARGENTM 001; Fuel Ethanol Application Sheet: AlphaAmylase and Glucoamylase Blend for Processing of Uncooked Starch. http://www.genencor.com, accessed in May 2010.

25. Hailong, L.; Xin-Sheng, C.; Yulin, D.; Huaiyu, Z.; Shiyu, F.; J. Chromatogr., A 2009, 1216, 69.

26. Wang, P.; Singh, V.; Xue, H.; Johnston, D.; Cereal Chem. 2007, 84, 10.

27. Wu, Q.; Miao, Y.; Carbohydr. Polym. 2008, 72, 398.

28. Baks, T.; Kappenb, F. H. J.; Janssen, A. E. M.; Boom, R. M.; J. Cereal Sci. 2008, 47, 214.

29. Białas, W.; Szymanowska, D.; Grajek, W.; Bioresour. Technol. 2010, 101, 3126.

30. Amutha, R.; Gunasekaran, P.; J. Biosci. Bioeng. 2001, 92, 560.

31. Ogbonna, C.; Okoli, E.; Process Biochem. 2010, 45, 1196.

32. Gi-Wook, C.; Hyun-Ju, L.; Yule, K.; Hyun-Woo, K.; Mina, K.; Bong-Woo, C.; Yang-Hoon, K.; Biomass Bioenergy 2010, 34 , 1223.

33. Rattanachomsri, U.; Tanapongpipat, S.; Eurwilaichitr, L.; Champreda, V.; J. Biosci. Bioeng. 2009, 107, 488.

34. Kosugi, A.; Kondo, A.; Ueda, M.; Murata, Y.; Vaithanomsat, P.; Thanapase, W.; Arai, T.; Mori, Y.; Renew Energ. 2009, 34, 1354.

Submitted: March 31, 2011 Published online: October 20, 2011 